\title{
O PRINCÍPIO DA PROTEÇÃO INTEGRAL SOB O ENFOQUE IBEROAMERICANO NA COOPERAÇÃO INTERNACIONAL DECORRENTE DO SEQUESTRO DE CRIANÇAS 1
}

Cláudio Franzolin

Professor da PUC-Campinas em regime de dedicação integral. Doutor em Direito pela Pontifícia Universidade Católica de São Paulo.

Fernanda Carolina de Araujo Ifanger Professora da PUC-Campinas em regime de dedicação integral. Doutora em Direito pela Universidade de São Paulo.

\section{Resumo}

O presente artigo apresenta uma pesquisa teórica, baseada nos ensinamentos emanados do Direito Internacional, do Direito Constitucional, do Direito Civil, do Direito Processual Civil e do Direito da Infância e Juventude, cujo objetivo é analisar a Cooperação Jurídica Internacional no que se refere, especificamente, ao problema do sequestro internacional de crianças. Evidencia-se a necessidade dos documentos internacionais sobre o tema, especialmente a Convenção de Haia, serem avaliados à luz do princípio da Proteção Integral, reitor inexorável das questóes relativas às crianças e adolescentes, segundo o qual deve ser buscada sempre a resposta que melhor atenda aos interesses e necessidades desses sujeitos de direitos. Ao final, apresenta-se a tese de que os casos de sequestro internacional de crianças, cujas decisóes acerca do destino do infante caiba ao Brasil, devem ser julgados pela Vara da Infância e Juventude, órgão melhor habilitado a decidir com base no princípio da Proteção Integral.

\section{Palavras-chave}

Direito Internacional; Direito da Infância e Juventude; Cooperação Internacional; Princípio da Proteção Integral.

\section{Resumen}

El artículo presenta investigación teórica, en las áreas del Derecho Internacional, Derecho Constitucional, Derecho Civil, Derecho Procesal Civil y Derecho de la Niñez y

1 Artigo submetido à avaliação visando a sua apresentação no III Encontro de Internacionalização do CONPEDI. 
Juventud, objetivando el análisis de la cooperación jurídica internacional en materia de sustracción internacional de menores. Parece evidente que los instrumentos internacionales que regulan esta materia deban ser estudiados y interpretados a la luz del Principio de Protección integral del menor; en especial las Convenciones de Haya, ya que él - Principio de Protección integral -, tiene que regir, inexorablemente, las cuestiones relativas a los niños y adolecentes, que obliga siempre se perseguir en los supuestos de hecho, la respuesta que más y mejor atienda a los intereses y necesidades de esos sujetos de derecho. Al final, se presentará una conclusión, en que en los procesos que versen sobre sustracción de menores en Brasil deban ser enjuiciados y decididos por los juzgados especializados en la infancia y juventud - que los hay en Brasil -, puesto estar mejores habilitadas a cumplir tal menester sobre las bases del Principio de Protección integral del menor.

\section{Palavras-clave}

Derecho Internacional; Derecho de la Niñez; Cooperación Internacional; Principio de Protección Integral.

\section{Introdução}

Quais os rumos para o século XXI²?

O Estado-nação deixa de ser a única referência no sistema internacional, despertando para uma necessidade de se (re)construir o sentido de soberania sob uma perspectiva de sociedade mais universalizada e integrada no ambiente Comunitário. Também, intensificam-se acordos para reprimir a criminalidade, por intermédio de mecanismos de Cooperação para a perseguiçáo dos agentes delituosos numa esfera transnacional. Ademais, a pessoa humana, com suas variadas diversidades e gêneros, torna-se titular de novos direitos e assume novas posiçóes jurídicas, como reflexo da igualdade substancial num ambiente de efetiva solidariedade internacional entre os Estados, ante a crescente interdependência das sociedades nacionais.

2 "A sociedade internacional desponta, em primeiro plano, como um necessário conjunto geográfico, resumido - até o momento - ao planeta Terra. A estrutura geográfica e política do planeta tece os contornos, os limites da sociedade internacional no século XXI. (...)”. (TEIXEIRA, 2013, p. 47). Mais a frente, situando o homem em seu caminhar para o século XXI, Carla Noura Teixeira aponta os seguintes aspectos: o homem está em sociedade; há um crescente desenvolvimento das ciências sociais; avanço tecnológico, o que reduz a distância de dados, informaçóes, valores, pessoas e fronteiras; e sob o prisma da sociedade internacional destaca que ela se torna descentralizada, pois não há autoridade superior, de forma que, explica a autora, neste Século XXI, o que se vislumbra é a possibilidade de o Estado, cada vez mais, organizarem-se horizontalmente, e dispostos a cederem, na medida do seu consentimento, inclusive, no que pertine às Cortes Internacionais. (TEIXEIRA, 2013, p. 50). 
Neste sentido, a concepção de proteção da pessoa humana não se esgota mais no âmbito do Estado, porque a sociedade tornou-se globalizada ${ }^{3}$, diante de tantas transformaçóes e, por conseguinte, estimularam-se novos paradigmas sob os mais variados prismas para compreender o fenômeno jurídico sob o enfoque transnacional ${ }^{4}$.

Em que pesem os mais variados impactos que se notam para o século XXI, um deles, seguramente, refere-se à efetivaçấo dos direitos das crianças, reconhecendo que o princípio da Proteção Integral se destaca como um comando que revela preocupação crescente com o bem-estar delas nas esferas nacional e transnacional.

A Constituição Federal brasileira tem como núcleo rígido fundamental a dignidade humana (art. 1º, da Constituição Federal/88), preceito orientador das liberdades e das garantias do ser humano. Nessa esteira, ganha destaque a tutela efetiva da criança, consoante o artigo 227 da Constituiçáo Federal, em conformidade com o princípio da Proteção Integral. E uma das formas de efetivação do referido princípio é a incorporação ao ordenamento jurídico interno da Convenção de Haia sobre o Sequestro Internacional de criança, cujo escopo é criar mecanismos específicos relacionados à Cooperaçáo Internacional para a devolução do infante, quando ele se submete a alteração abrupta de sua residência até entáo habitual, o que, seguramente compromete seu melhor interesse e sua proteção no cenário internacional.

Assim, evidencia-se que além da existência de um direito interno voltado a esses sujeitos de direito, Jacob Dolinger (2003, p. 80) reconhece que há um direito internacional da criança, enquanto, "uma coleçâo de diplomas legais que visam uniformizar o tratamento protetor das crianças de todos os povos ligados às organizaçóes internacionais e regionais", o que se revela em normas de conteúdo material e processual relacionados à efetividade jurisdicional nacional e internacional da criança à luz do princípio da Proteção Integral e do seu Melhor Interesse.

3 "Com a globalização, o Estado-Nação deixa de ser a única referência no sistema internacional, já que muitos problemas, alguns agentes econômicos e as tecnologias de informação se encarregam de dimensionar as estratégias à escala planetária. De tudo isso resulta algo (...) é que a globalização veio pôr em questấo a soberania como peça teórica chave do sistema internacional. (...) uma das marcas deste novo Direito Internacional é o de revalorizar a soberania considerando que a universalizaçáo da sociedade internacional leva a uma 'leitura tônica' da soberania (...)”. (PIMENTEL, 1999, p. 44).

4 Para Jayme (2003, p. 105) “(...) as coisas mudaram: existem fenômenos novos na visão pós-moderna do direito internacional privado e que refletem os quatro valores (...)". Explica o autor que os referidos valores são: pluralismo, comunicação, narração e retorno dos sentimentos. O primeiro é pluralismo, não apenas de formas, mas também de estilos de vida; o outro paradigma apontado por Erick Jayme é a comunicação significa que ela provoca a ruptura com as fronteiras, pois a troca de informaçóes e de imagens é quase que instantânea; o terceiro é a narração, ou seja, é o ato de argumentar, de descrever, de incorporar fatos e narrar novas situaçóes; e, segundo o autor, o quarto valor é o retorno ao sentimento, ou seja, significa valorizar o contexto cultural, a sensibilidade, o sentido em detrimento da racionalidade. Essas são as reflexóes que contribuem para fortalecer a operacionalização do sistema jurídico e seguramente, contribuir, no momento de como se deve interpretar o princípio do melhor interesse e da proteçâo da criança quando o debate transcende as fronteiras, no ambiente mais transnacional e globalizado. 
Assim, entre a variedade de situaçóes que envolvem as crianças, neste trabalho nos concentramos numa específica, qual seja, a condição de vulnerabilidade delas quando são retiradas de sua residência habitual e deslocadas para um Estado, por decisão unilateral e exclusiva de apenas um dos pais e a identificação das melhores respostas para esse problema, análise que envolve um complexo fenômeno jurídico - afinal, a criança é titular de direitos - e que deve ser estudado à luz do Direito Civil, do Direito Processual, do Direito Comunitário; e seguramente, em algumas situaçóes do Direito Penal.

Isto é, um dos genitores que, com o intuito de exercer com o exclusividade a guarda, transfere, compulsoriamente, os filhos para outro país e a partir daí, desencadeia-se a movimentação do aparelhamento estatal para a restituição da criança a sua residência habitual, com base na Convenção sobre Aspectos Civis do Sequestro Internacional de crianças, enquanto uma Convenção Quadro sobre a fixação de obrigaçóes entre os Estados-Partes no que pertine à Cooperação jurídica internacional ${ }^{5}$.

Afinal, se por um lado a movimentação de pessoas além das fronteiras é crescente e pode ocasionar danos, estes são acentuados quando envolvem crianças, já que elas são mais vulneráveis, haja vista que a decisão de movimentá-las não é delas, mas, sim, de um dos seus responsáveis (guardióes), bem como em razão de sua incapacidade de se opor, já que elas têm sua autodeterminação, muitas vezes, aniquilada ante a submissão ao poder familiar (do pai ou da mãe, seja o poder legítimo ou não).

O desenvolvimento, a crescente preocupaçáo com o destino das famílias e os impactos na vida dos filhos quando crianças, ao serem deslocados de um Estado para outro, seja em virtude de decisão voluntária e conjunta dos pais, seja em virtude da decisão compulsória e unilateral de um deles, fortalece o Direito Convencional, no intuito de fixarem-se medidas céleres e conjuntas entre os Estados, para o retorno da criança à sua residência habitual.

O que se impóe para este trabalho, então, é considerar o princípio da Proteção Integral e o princípio do Melhor Interesse, sob uma perspectiva mais transnacional, considerando o diálogo das fontes sob os aspectos substancial e processual, à medida que se despontam variados problemas, viabilizando um Direito Convencional e iniciativas em prol da proteção da criança que é removida ilicitamente por um dos pais, em detrimento do outro.

As questôes que levam à reflexão são: (a) como articular o princípio da proteção integral e do melhor interesse da criança num contexto pós-moderno e transacional? (b).

5 Artigo $1^{\circ}$. A presente Convenção tem por objetivo: a) assegurar o retorno imediato de crianças ilicitamente transferidas para qualquer Estado Contratante ou nele retidas indevidamente; b) fazer respeitar de maneira efetiva nos outros Estados Contratantes os direitos de guarda e de visita existentes num Estado Contratante. 
A Convenção de Haia que disciplina a Cooperação entre Estados em virtude de sequestro de crianças deve ser compreendida objetivamente, ou, o julgador que executa a medida de busca da criança pode contrariar a ordem de remoção, feita pelo Estado requerente, sob o fundamento de que o princípio da Proteção Integral está melhor efetivado no Estado solicitado? (c) Como articular o princípio da proteção integral e do melhor interesse em consonância com a tutela da criança decorrente de sequestro por um dos pais no contexto transnacional? (d) A manifestação de vontade da criança em querer manter-se no local em detrimento do sua residência habitual da qual foi retirada deve ser considerada pelo julgador?

Esses são alguns questionamentos que desafiam o presente trabalho.

\section{Princípio da Proteção Integral da Criança e sua Conformação Contempo- rânea ante 0 Sequestro de Crianças}

As normativas internacionais foram de fundamental importância para a modificação do trato de crianças e adolescentes no Brasil. Toda a legislação construída hodiernamente no Brasil, a partir da Constituição Federal de 1988, tomam como referência os documentos internacionais de proteção aos direitos humanos desses sujeitos.

Fato é que no século XX, de uma forma geral, ante a variedade de situaçóes às quais as crianças eram expostas, reconheceu-se a necessidade e a importância da garantia do bem-estar delas, o que motivou o reconhecimento em vários documentos internacionais do princípio da Proteçáo Integral em favor das crianças - e para o nosso sistema, também dos adolescentes ${ }^{6}$ - enquanto titulares de direitos que devem ser observados com prioridade imediata e absoluta.

Nesse diapasão, merecem destaque as seguintes disposições internacionais: (a) após a Primeira Guerra Mundial, a Organização Internacional do Trabalho foi a primeira a aprovar em 1919, a idade mínima para início da vida economicamente ativa; após, veio, a Declaração de Genebra, de 1924, aprovada pela Liga das Nações, destacando a necessidade de que a criança é titular de uma proteção especial; (b) Declaração Universal dos Direitos Humanos das Naçóes Unidas ${ }^{7}$, assegurando direitos especiais para a criança; (c) Resolução

6 O Estatuto da Criança e do Adolescente estabelece a diferença entre crianças e adolescentes ao determinar que as primeiras têm até doze anos incompletos e as segundas entre doze e dezoito anos incompletos.

7 "Artigo 25 Toda a pessoa tem direito a um nível de vida suficiente para lhe assegurar e à sua família a saúde e o bem-estar, principalmente quanto à alimentação, ao vestuário, ao alojamento, à assistência médica e ainda quanto aos serviços sociais necessários, e tem direito à segurança no desemprego, na doença, na invalidez, na viuvez, na velhice ou noutros casos de perda de meios de subsistência por circunstâncias independentes da sua vontade. A maternidade e a infância têm direito a ajuda e a assistência especiais. Todas as crianças, nascidas dentro ou fora do matrimónio, gozam da mesma proteçáo social". (DECLARAÇÃO, 1948). 
40.331/85, referente às Regras de Beijing, reconhecida pela Resolução 4.033/1985, da Assembleia das Naçôes Unidas; (d) Convenção Americana de Direitos Humanos ou Pacto de San José de Costa Rica, ratificado pelo Brasil em $1992^{8}$; (e) Convenção sobre os Direitos da Criança, de 1989, ratificada pelo Brasil, por intermédio do Decreto Legislativo 99.710, de 21/11/1990'.

A despeito da relevância de todos os textos mencionados, foi no ano de 1989, em Nova Iorque, que foi aprovado o mais importante documento em benefício dos direitos das crianças e adolescentes, o qual incorporou e inaugurou a doutrina da Proteção Integral. Pode-se dizer que ele iniciou a etapa positiva do tratamento diferenciado de crianças e adolescentes em cotejo com os adultos. Trata-se da Convenção das Nações Unidas sobre os Direitos da Criança, com força coercitiva para as naçóes signatárias, entre as quais estava o Brasil ${ }^{10}$.

A normativa foi ratificada, já naquele momento, por mais de 160 países, incluindo todos os da América Latina, sendo assinada pelo Brasil em 26 de janeiro de 1990 e aprovada pelo Decreto Legislativo 28, de 14 de setembro de $1990^{11}$.

A Convenção prevê de forma organizada e sistemática normas de proteção à criança e ao adolescente que durante toda a história da especialização da Justiça de Menores encontravam-se distribuídas em outros 80 documentos internacionais. Antes dela o único

8 "Art. 17 - Proteção da família. (...).4. Os Estados-partes devem adotar as medidas apropriadas para assegurar a igualdade de direitos e a adequada equivalência de responsabilidades dos cônjuges quanto ao casamento, durante o mesmo e por ocasião de sua dissolução. Em caso de dissolução, serão adotadas as disposições que assegurem a proteção necessária aos filhos, com base unicamente no interesse e conveniência dos mesmos”. (CONVENÇÃO, 1969).

9 A Convenção sobre Direitos da Criança (1990) reconhece a necessidade da criança ser titular de proteção especial: "1. Os Estados Partes respeitarão os direitos enunciados na presente Convenção e assegurarão sua aplicação a cada criança sujeita à sua jurisdição, sem distinção alguma, independentemente de raça, cor, sexo, idioma, crença, opiniāo política ou de outra índole, origem nacional, étnica ou social, posição econômica, deficiências físicas, nascimento ou qualquer outra condição da criança, de seus pais ou de seus representantes legais. 2. Os Estados Partes tomarão todas as medidas apropriadas para assegurar a proteção da criança contra toda forma de discriminação ou castigo por causa da condição, das atividades, das opiniōes manifestadas ou das crenças de seus pais, representantes legais ou familiares".

10 A Convenção das Naçôes Unidas sobre os direitos da Criança começou a ser redigida em 1979, convencionado como Ano Internacional da Criança, em comemoração aos vinte anos da Declaração Universal dos Direitos da Criança, e demorou dez anos para ser finalizada.

É ela considerada representação da segunda grande mudança ocorrida no trato das crianças e adolescentes, sendo a primeira a criação do Tribunal de Menores em Illinois. (GARCÍA MÉNDEZ, 1991).

11 Apenas dois anos após sua entrada em vigor a Convençáo contava com o maior número de ratificaçóes já visto relativamente a um tratado de Direitos Humanos, tendo-se destacado negativamente os Estados Unidos e a Somália pela não aceitação do documento. Importante ainda asseverar que os países que confirmaram a Convenção obrigaram-se também a apresentar ao Comitê dos Direitos da Criança relatórios anuais acerca de sua atuação governamental nessa seara. (MONACO, 2004). Entretanto, apesar de ratificarem a Convenção, nem todos os países elaboraram em curto prazo uma legislação que a contemplasse. 
texto universal a tratar da questão foi a Declaração dos Direitos da Criança, de 20 de novembro de 1959, que, no entanto, por sua natureza meramente declaratória, não tinha força vinculante para os Estados. (BARATTA, 1990-1991).

Objetivando oferecer proteção à criança e ao adolescente da forma mais abrangente possível, o documento disciplina as mais diversas situaçóes em que esse cuidado deve ser observado, tais como o direito a educação, a proteção em caso de conflitos armados, em situação de exploração sexual, o direito à saúde, a proteção contra violência, entre outras.

Ademais, ela consolida um conjunto de legislaçóes internacionais sobre o tema, que se convencionou denominar Doutrina das Naçóes Unidas de Proteção Integral da Infância, composta, além da própria Convenção, pelos demais documentos referentes aos infantes.

Duas disposiçóes demonstram claramente o novo olhar lançado sobre crianças e adolescentes: passam a ser considerados sujeitos, não mais objetos de direito, e acaba-se a equiparação entre abandono, delinquência e situação irregular, por meio da diferenciação entre jovens carentes de proteção - vítimas - e autores de condutas proibidas, ofertandose-lhes, pela primeira vez, tratamento jurídico diferenciado.

Fato é que,

precisamente, a proteção integral quer evitar a construção social que separa os 'menores' das crianças e dirige-se às crianças e adolescentes como sujeitos com direitos humanos originários, com a finalidade de evitar a sua marginalização e de reintegrar os 'menores' em desvantagem ou infractores o mais rapidamente possível no sistema normal da infância e da adolescência. (BARRATA, 1999, p. 73).

Reconhece-se, a partir de agora, que as crianças e adolescentes têm os mesmos direitos fundamentais assegurados a toda pessoa humana; têm direito, além disso, a uma proteção integral, bem como a instrumentos que assegurem seu saudável desenvolvimento físico, mental, moral e espiritual, em condições de liberdade e dignidade.

Em poucas palavras, a doutrina da Proteção Integral representa o "reconhecimento dos direitos da criança como uma categoria dos direitos humanos". (SOTOMAYOR, 1997, p. 99).

Trata-se de uma nova definição do papel do Estado e da sociedade civil diante das crianças e adolescentes carentes e também dos autores de atos infracionais. (LUCCHINI, 1991).

A ansiada mudança de paradigmas manifestou-se, então, em todos os aspectos da tratativa das crianças e adolescentes, tanto no tocante às políticas destinadas à sua proteção, quanto no que diz respeito às dirigidas à repressão das condutas ilícitas perpetradas 
por esses sujeitos. Nessa seara, a conquista da Proteção Integral para o adolescente consiste "em protegê-lo da medida e contra a injustiça de sua aplicação". (KONZEN, 2006, p. 343).

Assim, pode ser destacado como o maior avanço do novo pensamento o "estabelecimento de um verdadeiro empecilho para a utilização das mais diversas formas coativas, em especial por intermédio de internação, para aquelas crianças e adolescentes vítimas de desamparo social”. (SAENZ, 2008, p. 123).

Outrossim, foi ela ainda fundamental para a objetivação do direito e das práticas realizadas na seara da infância e juventude, objetivação essa no sentido de oposição à discricionariedade.(GARCÍA MENDEZ, 1998).

O que se evidencia é que "a proteção integral à infância e juventude situa, portanto, o sistema de justiça numa dimensão ético-política de proteger os mais vulneráveis, respeitando seus modos singulares de existência”. (VINCENTIN, 2006, p. 151).

Importante desvelar o pioneirismo do Brasil, nesse novo contexto de teorização e normatização das questóes referentes à infância e juventude.

A doutrina da Proteção Integral foi incorporada à legislação brasileira em 1988 por meio da edição dos artigos 227 e 228 da Constituição Federal - antes mesmo da finalização da Convenção -, sendo sua fonte de inspiração a Declaração dos Direitos da Criança da Assembleia das Naçóes Unidas de $1959^{12}$.

O referido artigo 227 é a primeira norma constitucional já escrita sobre a prioridade absoluta da criança e do adolescente e seus direitos humanos. Na expressão de Saraiva, agora, tornam-se esses sujeitos "a prioridade das prioridades do Estado". (SARAIVA, 2006, p. 188).

Na visão de Baratta (1990-1991), representa o citado mandamento a melhor síntese redigida acerca dos princípios que impóe a Convenção. É ele ainda que torna o antigo Código de Menores inconstitucional. (LUCCHINI, 1991). _

Sobre a importância dessa constitucionalização do direito da infância dissertou García Méndez (1998, p. 69) que "um novo tipo de direito constitucional inspirado na Convenção abre as portas para uma nova reformulação do pacto social, com todas as crianças e adolescentes como sujeitos ativos do novo pacto".

A Constituição Federal de 1988 assegurou as crianças e adolescentes todos os direitos e garantias conferidos aos adultos, além de outros, a eles específicos, consequência de sua consideração como pessoas em desenvolvimento. Criou, portanto, uma "desequiparação

12 Nessa incorporação foi fundamental a atuação do movimento chamado A Criança e o Constituinte, movimento da sociedade civil e de milhares de crianças visando a inserçâo no texto constitucional dos princípios expressos na Declaração dos Direitos da Criança. 
jurídica protetiva" (MACHADO, 2006, p. 100) em favor dos sujeitos ainda em desenvolvimento.

$\mathrm{Na}$ esteira do pioneirismo do texto constitucional, o Estatuto da Criança e do Adolescente foi uma das primeiras legislações em âmbito mundial, e a primeira da América Latina, a adotar a doutrina da Proteção Integral. Trata-se, para Baratta (1995), da legislação que melhor acolheu o espírito e a letra da Convenção ${ }^{13}$.

Sua importância está no fato de que "estabeleceu o estado democrático de direito num contexto em que estivera ausente desde a formação histórica do Brasil, abolindo o subjetivismo, o arbítrio, consagrando e dignificando a justiça”. (CAMARGO SOBRINHO, 200, p. 115).

A doutrina da Proteção Integral, consoante já explicitado, garante direitos aos jovens em todas as situaçóes em que eles se encontrem, o que não deixou de ser observado pelo Estatuto da Criança e do Adolescente.

Em seu modelo sistêmico, os direitos e deveres das crianças e adolescentes podem ser agrupados em três conjuntos diversos, denominados também de etapas da tutela estatal, cada qual deles identificado a partir de um prisma de prevenção.

A prevenção primária, representada pelas políticas básicas, tem por escopo assegurar direitos a todas as crianças e adolescentes, indistintamente, tais como saúde, alimentação, habitação, educação, transporte profissionalização e cultura. A prevenção secundária, na qual se inserem as políticas de proteção especial, inclui as medidas de proteção, guarda, renda familiar mínima, atendimento às vítimas de maus tratos, abrigamento, guarda subsidiada, entre outras, destinadas aos sujeitos vitimizados ${ }^{14}$. Por fim, a prevenção terciária é composta pelas políticas socioeducativas, que englobam as sançôes aplicáveis aos adolescentes autores de atos infracionais, denominadas de medidas socioeducativas. (SPOSATO, 2006).

É no âmbito da prevenção secundária que se insere a questão do sequestro internacional de crianças.

Consoante explicitado na introdução, a expressão refere-se ao "deslocamento ilegal da criança de seu país e/ou a sua retenção indevida em outro local que não o da sua residência habitual". (SIFUENTES, 2009, p. 228).

13 Para García Méndez (1998, p. 60) "a partir da experiência do Brasil, todo o resto das reformas legislativas (com maior ou menor nível de participação social e com uma melhor ou pior técnica jurídica), deixaram de ser esotéricas e clandestinas reuniōes de 'peritos' que trabalham nos sótãos dos Ministérios de Justiça, para converterem-se em imensos laboratórios político-sociais de produção jurídica democrática”.

14 Nesse sentido, relata Passetti (1995, p. 51) que "a partir do momento em que o Estado náo preenche a lacuna deixada pelo Mercado, ou seja, a situação de desemprego, carência, abandono e falta de escolaridade, ele pode ser entendido como um violentador, por não cumprir com a responsabilidade que ele próprio se atribuiu: a de tutor de todos os pais". 
Conforme esclarece Dolinger (2003), a tradução do termo é feita à partir da expressão abduction, em inglês - ou kidnapping - e corresponde ao deslocamento por intermédio da decisão de um dos pais que afasta do contato com o outro que está, à princípio, incumbido da guarda; ou, ainda, decorre da não devolução da criança levada por um pai, durante o período que lhe é assegurada a visitação. Já, o termo adotado pelo direito francês, denominado enlèvement international d'enfants, é, na visão do autor, o mais adequado, pois ao traduzi-lo, no vernáculo corresponde à "retirada".

Não se trata, pois, de sequestro nos moldes disciplinados na legislação penal, uma vez que se cuida aqui dos aspectos civis do sequestro internacional de crianças.

Diante da incorporação da Convenção de Haia ao ordenamento jurídico brasileiro, o país passa a comprometer-se a dar tratamento prioritário aos casos de sequestro internacional de crianças, os quais não encontravam nenhuma disciplina legal no ordenamento jurídico interno.

Pode-se perceber, então, que o fundamento principal da Convenção "é a garantia dos interesses da criança e sua proteção contra os efeitos prejudiciais resultantes de uma mudança abrupta de domicílio" 15

Reconhece-se, enfim, a gravidade do problema que ao impor a repentina retirada das crianças de suas moradas e inseri-las abruptamente em um ambiente totalmente distinto daquele em que estavam acostumadas a viver elas passam a tomar contato com uma variedade de valores, virtudes, situações existenciais, costumes, enfim, hábitos, repercutindo, negativamente, na estrutura bio-físico-psíquica e em seu desenvolvimento.

Não há mais, nesse contexto, como pensar na Proteção Integral desses sujeitos e olvidar-se desse novo problema social, cada vez mais presente na sociedade globalizada, cujas consenquências sobre suas vítimas são bastante gravosas.

O mencionado documento, datado de 1980, foi ratificada pelo Decreto Legislativo 79, de 15 de setembro de 1999 e promulgado em 14 de abril de 2000, por meio do Decreto Presidencial n. 3.413, denominando "Sequestro internacional de crianças", sendo que somente em 4 de outubro de 2001 foi designada a Autoridade Central incumbida de dar cumprimento às obrigaçóes impostas pela Convenção.

Após extensas discussóes, os países signatários da Convenção de Haia entenderam que a melhor solução para a celeuma seria a determinação do retorno da vítima para o

15 "Os Estados signatários da presente Convenção, firmemente convictos de que os interesses da criança são de primordial importância em todas as questôes relativas à sua guarda; desejando proteger a criança, no plano internacional, dos efeitos prejudiciais resultantes de mudança de domicílio ou de retenção ilícitas e estabelecer procedimentos que garantam o retorno imediato da criança ao Estado de sua residência habitual, bem como assegurar a proteção do direito de visita; decidiram concluir uma Convenção para esse efeito e acordaram nas seguintes disposiçōes ”. (CONVENÇÃO, 1980). 
Estado de sua última residência para que o magistrado desse local decidisse sobre a fixação da guarda da criança.

Tal proposta leva em consideração a Proteção Integral que rege as novéis normativas relativas às crianças e adolescentes, especificamente a partir da consideraçáo dos princípios da condiçáo peculiar da pessoa em desenvolvimento e do melhor interesse da criança, também chamado de interesse superior, os quais devem guiar toda a interpretação que se faça das regras referentes às crianças e adolescentes, em quaisquer das esferas de prevenção anteriormente mencionadas.

O primeiro supera a categoria discriminadora da menoridade ao estabelecer que cada faixa de desenvolvimento tem suas singularidades, as quais devem ser observadas e respeitadas pelo Estado, pela família e pela sociedade.

O segundo, por sua vez, determina sejam privilegiados os interesses e as necessidades da criança em todas as situaçóes em que elas se inserem, devendo ser tomada sempre a resposta que melhor as atenda.

Tratando-se do problema específico do sequestro internacional de crianças, não se pode conceber seja tomada uma decisão em dissonância com os princípios reitores de toda a interpretação das questóes relativas à infância, devendo eles serem respeitados por todos os Estados Nacionais, bem como no âmbito da Cooperação Jurídica Internacional.

Fundamental que se destaque a mudança paradigmática que a aprovação dos mencionados documentos, bem como do Estatuto da Criança e do Adolescente, propiciou no tocante à proteção das crianças e adolescentes.

Antes deles, toda legislação nacional destinada à infância e juventude era inspirada pela doutrina da Situação Irregular, teorização que, no âmbito nacional, serviu como base para os Códigos de Menores de 1927, conhecido como Código de Mello Matos, e de 1979 (Lei 6.697/79) ${ }^{16}$.

Sob sua égide, o tratamento jurídico especificamente dirigido aos não-adultos tinha como fundamento a consideração da infância como categoria diversa da adulta, em virtude da incapacidade inerente a esse grupo de pessoas. (COSTA, 2005).

Entendia-se que todas as decisôes sobre esses indivíduos deveriam ser tomadas pelos adultos, os quais não deveriam preocupar-se com os interesses e especificidades dos não-adultos.

Para usar a expressão de Zaffaroni (1994, p. 84), é a representação da máxima "discriminação biológica em relação aos menores”.

16 No Contexto específico da América Latina, as citadas etapas da especialização podem ser cronologicamente determinadas: a primeira iniciou sua hegemonia a entre 1919 e 1939 e a segunda no de 1990. (GARCÍA MÉNDEZ, 1998). 
É em observância à premissa mencionada que se construiu a categoria “menor”, avaliado como um ser incompleto e inadaptado que só consegue, com ajuda, reincorporar-se à sociedade. (SOTOMAYOR, 1997).

Diante disso, essa ideologia

converte a criança e o jovem em objeto, não em sujeito de direitos, em um ser dependente, que há de ser submetido a intervenção protetora e educadora do Estado, a qual é profundamente seletiva, pois irregular ou perigoso se iguala com situação de abandono, é dizer, com as crianças e adolescentes pertencentes as classes ou grupos mais desfavorecidos e, portanto, onde os processos de socialização foram mais deficitários e isso se pretende substituir através de medidas sancionatórias. A ideologia da situação irregular, protetora ou educativa, provoca uma identificação entre proteção a criança e sanção, sobre a base de um pretendido objetivo de beneficência ou bem-estar. (BUSTOS RAMÍREZ, 1997, p. 63).

Destarte, para García Méndez (1990-1991), a extensão do uso da doutrina da Situação Irregular foi inversamente proporcional à extensão e qualidade das políticas sociais básicas.

Evidente, ante o exposto até aqui, que a proteção na fase tutelar não era concebida sob a ótica dos direitos fundamentais. Também não se organizava o ordenamento jurídico sob a premissa de que crianças e adolescentes tinham os mesmos direitos humanos dos adultos. (MACHADO, 2006).

Trata-se, de acordo com García Méndez (1998, p. 64), de "uma justiça com as aparências objetivas e abstratas da lei, mas com os conteúdos e o funcionamento real da discricionariedade médica”. Misturava-se assistencialismo com um ideal abstrato de justiça para a realização do saneamento moral dos menores. (SHECAIRA, 2008).

Isto posto, evidente que não se pode mais olhar para o problema do sequestro internacional de crianças sob a ótica desse enfoque que tantos malefícios causou. Diante das novéis normativas aprovadas em favor das crianças e dos adolescentes, o diálogo das fontes fortalece que o retorno da criança à sua residência habitual não pode ocorrer sem considerar o princípio da Proteção Integral e do Melhor Interesse da criança.

\section{Perspectivas Substancial e Processual na Cooperação Internacional De- corrente de Sequestro de Crianças}

Compreender a Cooperação Jurídica Internacional em matéria de sequestro de crianças necessariamente pressupóe o estudo da Convenção Internacional de Haia ${ }^{17}$, que

17 A respeito da Convenção de Haia, o que merece consideração diz respeito a sua importância no âmbito do direito internacional privado, no intuito de, sempre, aperfeiçoar a colaboraçáo entre os Estados os quais, 
disciplina a busca, a apreensão e a devolução da vítima para o país de origem, bem como da Convenção Interamericana sobre restituição de menores (Cirim) de 1989, a qual vigora para os Estados Membros da Organização dos Estados Americanos, conforme dispóe seu artigo 34, inspirada na Convenção de Haia, consoante esclarecem Gaspar e Amaral (2013) em artigo científico sobre o sequestro de crianças por atuação parental.

Particularmente, no artigo $1^{\circ}$ da Convenção de Haia (1980) fixam-se dois objetivos a serem buscados diante da retirada forçada da criança de seu lar, os quais ela destaca expressamente: "assegurar o regresso imediato das crianças ilicitamente transferidas para qualquer Estado Contratante ou nele retidas indevidamente" bem como "fazer respeitar de maneira efetiva nos outros Estados Contratantes os direitos de custódia e de visita existentes num Estado Contratante”.

Por essas disposiçóes, resta evidente que a preocupação da Convenção é com o retorno imediato da criança para o país de origem, de onde foi retirada. A despeito da primazia desta resposta, não se pode afirmar que o regresso do infante ao país onde residia seja, necessariamente, a soluçáo que melhor atenda aos seus interesses e necessidades.

Sendo assim, a Convenção em questão, se por um lado impóe um ajuste de efetivação de execução de medidas para assegurar o retorno imediato da criança para a sua residência originária, por outro lado não pode ser compreendida em dissonância com os valores constitucionais, com os fundamentos princípiológicos do Código Civil, com a efetividade decorrente do Processo Civil, com a prioridade na tutela da criança no âmbito das varas especializadas do Estatuto da Criança e do Adolescente e com os fundamentos do Direito Internacional Privado.

Vale destacar ainda que a Cooperação Internacional significa estabelecer um conjunto de medidas que visam a implementar - tanto sob o aspecto administrativo como jurisdicional - a fixação de competência e a melhor interpretação da Convenção. Nesse diapasão, mister considerar se a decisão de um Estado Solicitado em devolver a criança pode ser acolhido, haja vista que é preciso levar em conta os princípios da Proteção Integral e do Melhor Interesse da Criança.

Para que possamos, primeiramente, considerar a análise da Cooperação Internacional à luz da Convenção de Haia, tomaremos como situação inicial o emblemático caso de

embora soberanos "no que concerne à Conferência da Haia de Direito Internacional Privado, é ela dotada de um objetivo próprio, sua funçâo institucional reconhecida por seus Estados membros: a persecução da unificação progressiva do direito internacional privado entre seus Estados membros. Quer isso significar que os Estados que a compôem concordam com tal atividade e a desejam. Devem, portanto, em princípio, colaborar para a sua obtenção, por meio da participação efetiva nas reuniốes realizadas para a preparação de projetos de convençóes internacionais; e das negociaçóes travadas em suas sessóes diplomáticas e que desembocam na assinatura do texto final, passando pela assinatura formal da convenção e pela adoção interna de seu conteúdo, por meio da ratificação”. (RODAS; MÔNACO, 2007, p. 190). 
Sean Goldman que culminou não apenas numa apreciação quanto ao Melhor Interesse e a Proteção Integral da criança, mas ganhou foro de relaçóes internacionais num debate entre o Presidente dos Estados Unidos Barack Obama e o Presidente da República Federativa do Brasil, à época, Luiz Inácio Lula da Silva.

A partir deste caso poderemos também dedicar algumas consideraçóes sobre a necessidade ou não da interferência do Juízo Federal e da apreciação pertinente pelo Estado Solicitado na recusa em devolver a criança.

\section{Considerações sobre o Caso Sean Goldman no Âmbito do Direito Interna- cional Privado Envolvendo Litígio Decorrente}

Entre tantos casos de sequestro internacional de crianças merece destaque o do menino Sean Goldman, em razão de sua grande repercussão nacional e internacional e da intensidade das discussóes que gerou.

Sean Richard Bianchi Carneiro Ribeiro Goldman nasceu em Nova Jersey, nos Estados Unidos, fruto da união entre o americano David George Goldman e a brasileira Bruna Bianchi Carneiro Ribeiro. A família vivia nos Estados Unidos, mas numa das vindas da mãe ao Brasil junto com seu filho, esta optou por não mais retornar com o menino para os Estados Unidos ${ }^{18}$.

Já no Brasil, a genitora casa-se com João Paulo Lins e Silva, e no parto de sua segunda filha vem a falecer. Inicia-se, então, uma batalha judicial entre o padastro e avós maternos e o pai biológico que pleiteava judicialmente a devolução do seu filho para com ele viver em Nova Jersey.

18 Direito processual civil. Busca e apreensão de menor. Pai americano. Mãe brasileira. Criança na companhia da mãe, no Brasil. Convenção de Haia sobre os Aspectos Civis do Sequestro Internacional de Crianças. Embargos de declaração no recurso especial. Ausência de omissōes. Prestação jurisdicional encerrada. Prequestionamento de dispositivos constitucionais. Vedação. As questôes suscitadas pelo embargante não constituem pontos omissos do julgado, mas mero inconformismo com os fundamentos adotados pelo acórdão recorrido, sedimentados em firme ponderação e consequente escorreita aplicação dos dispositivos da Convenção de Haia sobre os Aspectos Civis do Sequestro Internacional de Crianças, nada havendo para reformar ou esclarecer no julgado. O que se percebe, é que busca o embargante, por meio de uma tese transversa, modificar o julgado, fugindo aos parâmetros estabelecidos pelo aludido tratado internacional, que busca, primordialmente, defender os interesses e direitos da criança, e não, como quer fazer prevalecer o embargante, os interesses dos genitores, quer seja o pai, quer seja a mãe do menor. A tal respeito, consigne-se que cabe aos pais uma postura que minimize o sofrimento da criança, de forma que possa usufruir da presença de ambos, da melhor forma possível, sem que se sinta compelida a adotar os nem sempre muito racionais - porquanto em aberto litígio -, posicionamentos de um ou de outro genitor. As questóes trazidas à debate pelas partes não demarcam a fundamentação a ser adotada pelo julgador, que pode valer-se dos temas jurídicos que entender de Direito para alcançar o deslinde da controvérsia. (...). Embargos de declaração rejeitados. BRASIL. Supremo Tribunal Federal. Recurso Especial n. 900.262. Relatora Nancy Andrighi. 
Assim, enquanto no Brasil o padrasto ajuizou a ação declaratória de paternidade sócio-afetiva de Sean, nos Estados Unidos seu pai biológico propôs demanda para exigir do Estado brasileiro, a devolução do filho para viver com o seu genitor sobrevivente, confirmando-se a decisão de definição da guarda em seu favor para o filho Sean viver com ele em Nova Jersey.

Nesta rota, a União, visando a efetivação da decisão da Corte estadunidense ajuizou ação perante a Justiça Federal, para a busca e apreensão de Sean, considerando que, ante a morte da mãe, ele ficaria, a partir de então, sob a guarda definitiva do pai biológico e é justamente o que ocorreu ao final da demanda.

\section{Cooperação Internacional Ativa e Passiva e o Juízo Competente: Uma Abordagem Contemporânea para a Efetivação dos Direitos Fundamentais da Criança e Breves Considerações sobre a IberRed}

Quando se estuda sobre a Cooperação Internacional efetiva-se a devolução da criança para o Juízo do Estado Solicitante. (SIFUENTES, 2009). Contudo, conforme se tem defendido no presente artigo, na tomada dessa decisão, o princípio da Proteção Integral deve ser analisado e considerado pelo Estado encarregado de cumprir e executar a ordem de busca e apreensão.

Neste sentido, podem ser mencionadas, exemplificativamente, dois caos em que a celeuma foi resolvida com a observância da Proteção Integral das crianças envolvidas.

Em uma delas, os pais eram divorciados e a criança de tenra idade foi deslocada dos Estados Unidos para o Reino de Gales, sendo que na discussão acerca da celeuma determinou-se como necessária a apreciação dos interesses da vítima e não apenas da situação relacionada a conduta ilícita ou ilícita de quem detinha a guarda quando decidiu manter a criança e removê-la para outro país ${ }^{19}$.

19 Uma criança de 3 anos foi retirada de sua residência habitual que era no Colorado, nos Estados Unidos, e a mãe o levou para o País de Gales, que era o estado natal dela. Por outro lado, no Condado de Adams, Colorado, nos Estados Unidos, havia uma guarda provisória em favor da máe que seria revista 14/7/1994. Em 31/10/1994, foi determinado pelo Tribunal nos Estados Unidos que a criança deveria ser restituída para a sua residência habitual, tomando como base que tinha havido um traslado ilícito da criança para outro país sem que o pai soubesse. Inclusive, destacou a sentença que no Estado do Colorado, os pais detém poder parental em igualdade de condiçóes, e por isso, o traslado na forma que foi feito, obstaculiza o direito de visita por parte do pai. Por outro lado, quando o Pais de Gales recebeu a ordem para devolver a criança para os Estados Unidos, mas não deu prosseguimento na ordem. Destacou o Tribunal no Reino Unido que a decisão por uma autoridade jurisdicional no Estados Unidos determinado a devolução da criança náo confere cumprimento automático pelo Estado solicitado, apenas porque firmou-se a Convenção envolvendo sequestro de criança por um dos pais. Destacou o Tribunal britânico que a criança presenciou vários atos de violência contra a mãe e que, inclusive, também foi vítima por atos de violência praticado pelo seu pai. Ademais, destacou o julgado que por isso, com base no artigo 13, I, 
Em outra situação, mais propícia ao debate, a mãe tinha a custódia e a guarda da filha quando morava em Hong Kong. No entanto, ao deslocar-se para os Estados Unidos, levou consigo sua filha. Ao chegar ao novo país a genitora solicitou alimentos para o sustento da menina, enquanto, concomitantemente, o pai, em Hong Kong, requereu a devolução da mesma. A situação fez com que o pai comunicasse o fato à polícia desaguando num pedido lastreado na Convenção de $\mathrm{Haia}^{20}$.

Desse modo, evidente que o caso não se resolve meramente com ao retorno da criança ao Estado solicitante, sendo mister seja essa solução compatível com a garantia dos interesses e necessidades do infante.

A respeito do tempo considerado adequado para a tomada de uma decisão diante do sequestro internacional de uma criança, estabelece a Convenção que a resposta ao conflito deve ser mais célere possível, tanto que seu artigo $2^{21}$ reconhece a necessidade de que o Estado seja aparelhado para concretizar os objetivos da Convenção de forma que as medidas necessárias sejam adotadas urgentemente, sempre considerando que a criança não pode ficar numa situação de irregularidade e de instabilidade quanto a sua guarda.

No Brasil, o órgão designado para executar as obrigaçóes da Convenção, a Autoridade interna, é a Secretaria Especial dos Direitos Humanos - SEDH, da Presidência da

da Convenção, que só por isso, já é o suficiente para se recusar a não prosperar na execução de medida de devolução da criança. E mais, que a criança demonstrou grande temor ao saber que corria o risco de ser devolvida para a resdiência habitual que era nos Estados Unidos. Em suma, não se prosseguiu para cumprir a ordem o que desencadeou um conflito entre o Estado Contratante e o Estado solicitado (tradução nossa). (REINO UNIDO; INGLATERRA; GALES. Tribunal de Apelaciones. Apelação).

20 Trata-se de uma criança de 9 anos que vivia em Hong Kong, e que seus pais eram divorciados. Por sua vez, a mãe tinha a guarda, em caráter exclusivo tendo o pai direito de visitação. Ademais, na decisão de Hong Kong havia uma determinação que quaisquer traslados deveria ocorrer com autorização do outro progenitor. Em 2 de abril de 1999, a mãe, unilateralmente, levou a criança para Nova York; ademais, a mãe, também, apresentou uma ação no Tribunal de família do Condado de Nova York, requerendo a custódia da criança e também pedido de alimentos. Em 22 de abril, em Hong Kong, o pai comunicou à polícia que a criança tinha desaparecido. Em 14 de maio, os Estados Unidos recebeu um pedido de restituiçáo da criança para Hong Kong e. por sua vez, o Tribunal dos Estados Unidos do Distrito Sul acolheu a ordem para determinar a devolução da criança. Incontinente, houve uma ordem do Tribunal superior suspendendo a devolução. Alegou-se que o pai, naquele país oriental, não detinha poder de custódia. Destacou que concorre com o direito de custódia, uma série de outros direitos que os pais devem possuir para serem legitimados e amparados pela Convençáo, no momento de requerer a devolução. Ademais, fixou que o pai não tinha o direito de definir sobre a residência da criança, já que a guarda era da mãe o que lhe garantia custódia exclusiva. E, considerando os desdobramentos que envolvem a guarda, entre um deles, de fixar a residência da criança, foi denegada a ordem para determinar a devolução dela para Hong Kong. (ESTADOS UNIDOS. United States Court of Appeals for the second circut. Apelação).

21 "Artigo 2 - Os Estados Contratantes deverão tomar todas as medidas apropriadas que visem assegurar, nos respectivos territórios, a concretização dos objetivos da Convenção. Para tal, deverão recorrer a procedimentos de urgência” (CONVENÇÃO, 1980). 
República, denominada, Autoridade Central Federal, nos termos do Art. $6^{0} .{ }^{22}$ do referido documento.

O que merece destaque é que a criança protegida pela Convenção é a que tem residência habitual em um dos Estados contratantes e que é deslocada em virtude da quebra ao impedimento do direito de visita. Quem remove a criança pode ser qualquer um dos pais ou alguém impedido de ter contato com ela, como, por exemplo, um dos avós, sempre lembrando que a situação de guarda pode ser de fato ou de direito no Estado solicitante (Estado ativo).

Diversos aspectos devem ser observados na análise das disposiçóes da Convenção em relaçấo ao sequestro internacional de crianças.

Sob o aspecto formal-processual, vale destacar que o Brasil fez a reserva, constante do seu artigo $24^{23}$, considerando a indispensabilidade da realização de tradução juramentada para o português dos documentos estrangeiros nas situaçôes em que o Brasil é o Estado passivo que pode ser responsabilizado pela efetivação da Cooperação em território nacional ${ }^{24}$.

No tocante à esfera jurisdicional, é preciso avaliar acerca do juízo competente para o qual deve recorrer aquele que pleiteia o desfazimento dos efeitos do sequestro.

22 "Art. 6 - Cada Estado Contratante designará uma Autoridade Central encarregada de dar cumprimento às obrigaçôes que lhe são impostas pela presente Convenção. Estados federais, Estados em que vigorem vários sistemas legais ou Estados em que existam organizaçôes territoriais autônomas terão a liberdade de designar mais de uma Autoridade Central e de especificar a extensão territorial dos poderes de cada uma delas. O Estado que utilize esta faculdade deverá designar a Autoridade Central à qual os pedidos poderão ser dirigidos para o efeito de virem a ser transmitidos à Autoridade Central internamente competente nesse Estado". (CONVENÇÃO, 1980).

23 "Art. 24 - Os pedidos, comunicaçóes e outros documentos serão enviados na língua original à Autoridade Central do Estado requerido e acompanhados de uma tradução na língua oficial, ou numa das línguas oficiais, desse Estado, ou, quando tal tradução for dificilmente realizável, de uma tradução em francês ou inglês. No entanto, um Estado Contratante poderá, fazendo a reserva prevista no Artigo 42, opor-se à utilização seja do francês, seja do inglês, mas não de ambos, em todo pedido, comunicação ou outro documento enviado à respectiva Autoridade Central”. (CONVENÇÃO, 1980).

24 "O Brasil, que é parte em duas Convençóes da Haia, formulou reserva ao art. 24 da Convenção sobre os aspectos civis do sequestro internacional de crianças, segundo autorização do art. 42 do mesmo diploma convencional. O artigo reservado regula a comunicação entre as autoridades entrais que devem se desincumbir das obrigaçóes impostas pelo tratado. Segundo a disposiçấo, as comunicaçôes devem ser feitas na língua original do Estado que formula a comunicação, acompanhada de uma tradução na língua oficial ou em uma das línguas oficiais do Estado a que se dirige a comunicação, abrindo a possibilidade de que, se esta tradução for de difícil obtenção, se faça uma tradução para o francês ou o inglês, línguas oficias da Conferência. Admite-se que seja feita reserva a esse artigo, no entanto, quanto à utilização do francês, ou do inglês, na última hipótese explicitada, mas nunca de ambos os idiomas. A reserva formulada pelo Brasil, no entanto, refere-se à necessidade de que a tradução encaminhada em português para a Autoridade Central brasileira, o seja segundo tradução pública juramentada, (...). Dessa reserva formulada foi dado conhecimento amplo aos demais Estados parte da Convençáo". (RODAS; MÔNACO, 2007, p. 222). 
No que se refere à competência ${ }^{25}$ para decidir sobre o sequestro internacional podese identificar a existência de um importante conflito: se por um lado, há a competência da Justiça Federal (art. 109, I e III, da CF/88); por outro lado, há uma justiça especializada que é o Juízo da Infância e Juventude.

Diante desse conflito, dois aspectos normativos precisam ser considerados.

A competência da Justiça Federal é fixada no artigo 109 da Constituição Federal, em razão do território (art. 109, $\$ \$ 1^{\circ}$ e $2^{\circ}$ ), da matéria (art. 109, III), da pessoa (art. 109, I, II, VII, VIII, X, XI) e da função (art. 109, VIII). Afinal, a competência jurisdicional é determinada, primeiramente, a partir da Constituição Federal, e no artigo 109, III, ela fixa, taxativamente, a competência da Justiça Federal para processar e julgar as causas fundadas em tratados ou contratos da União com Estado estrangeiro ou organismo internacional (art. 109, III), bem como as causas em que a Uniāo for interessada sob quaisquer fundamentos (art. 109, I, da CF).

Para fixar a competência da Justiça Federal, considerando a situação Convencional e a decisão de se fixar sua competência com base no artigo 109, III, e nem a fixação da competência da justiça federal baseada no art.109, V, para o deslinde de crimes fundados em Direito Convencional, porque a Convenção de Haia sobre aspectos civis de Sequestro de Menores, não cuida de crime, e sim, de situação de direito de família e tutela da criança; finalmente, funda-se a competência da justiça Federal, porque a Autoridade Interna é federal, e não tendo ela, capacidade postulatória, quem atua é a Advocacia da União e nesse caso, por força, do artigo 109, I, também ela é interessada, só por sí, já envolveria o deslocamento para a referida justiça.

Não concordamos com nenhum dos fundamentos apontados.

Sob nosso ponto de vista, a tutela jurisdicional deve determinar como órgão competente a Vara da Infância e da Juventude, enquanto justiça especializada, com fundamento no art. 227, da CF/88.

A Constituição Federal coloca em prioridade absoluta, o interesse da criança e do adolescente, destacando vários direitos básicos e fundamentais desses sujeitos. Ademais, como decorrência da efetivação do dispositivo constitucional mencionado, o Estatuto da Criança e do Adolescente, no seu artigo 145, estabelece que os Estados federados e o Distrito Federal poderão criar varas especializadas e exclusivas da Infância e da Juventude, cabendo ao Poder Judiciário estabelecer sua proporcionalidade por número de habitantes.

25 A noção de competência encontra-se atrelada a da função jurisdicional. Enquanto esta conforme expóe Marinoni (2008, p. 115), deve "dar tutela aos direitos, e não apenas dizer quais os direitos merecem proteção”, ou seja, "a função jurisdicional é uma consequência natural do dever estatal de proteger os direitos, a qual constitui a essência do Estado contemporâneo”, aquela refere-se à distribuição da atividade jurisdicional entre os órgãos do Poder Judiciário. 
Não é só. Consoante dispóem as Regras de Beijing, a Justiça da Infância e Juventude é reconhecida como um sistema especial para a tutela da criança, o que legitima a existência de um Juízo especializado, conforme se depreende dos artigos 98, 148, parágrafo único, 149, 150 e 151, todos do Estatuto da Criança e do Adolescente.

Assim, há uma atração das Varas da Infância e da Juventude para avaliar a situação da criança e para efetivar a sua tutela quando envolve a Convençáo sobre aspectos civis de sequestro desses sujeitos. Afinal, há um aparelhamento estatal voltado de forma especial para esse fim.

Desse modo, na definição para a tutela da criança em situaçóes relativas a Cooperação Internacional e a incidência da Convenção da Haia é preciso considerar que a criança é um sujeito vulnerável e titular de direitos fundamentais, isso inclusive como exigência do Estado, com fulcro na Constituição Federal, o que permite concluir que o Juízo da Vara da Infância e da Juventude é o órgão mais preparado para decidir o caso, tomando em mais alta consideração a Proteção Integral e o Melhor Interesse da criança.

O que se defende, então, é que, no âmbito da justiça especializada estadual, é possível processar e julgar o processo relativo ao direito de guarda, o que irá guarnecer melhor os interesses da criança.

A Justiça Federal é afetada, apenas, para ser competente, no intuito de se efetivar uma Cooperação Internacional, mas esta situação não pode superar e sopesar como de maior importância do que o Interesse Superior da criança, desdobramento, decorrente do Princípio da Proteção Integral.

Outro aspecto que também corrobora com a fundamentação apresentada pode ser depreendido do Novo Código de Processo Civil - promulgado em 2015 - , que em nada impede que possa a vara especializada avaliar a necessidade ou náo, a efetividade ou náo da medida de busca e apreensão de criança quando envolve a Convenção a respeito de sequestro de crianças.

Isso porque é o Novo Código de Processo Civil invadido de premissas axiológicas decorrentes de um Estado Democrático e Social e marcado por rupturas com o logicismo e com a racionalidade para dar lugar a um ambiente propício para que o processo realize uma comunicação argumentativa e efetive, internamente, mais cooperação entre os envolvidos - partes, auxiliares, juízo. Tanto que seu artigo $6^{\circ}$ estabelece que "todos os sujeitos do processo devem cooperar entre si para que se obtenha, em tempo razoável, decisão de mérito justa e efetiva”, o que significa uma ampliação da demanda e num contraditório mais elaborado e mais dinâmico.

Evidente, então, a preocupação da nova legislação com a realização dos direitos fundamentais o que, seguramente, irá contribuir para a realização da tutela da criança no âmbito das relaçóes internacionais, que é o foco deste trabalho. 
Assim, após ter sido dado o primeiro passo, em 1993, com o Tratado de Mastricht, que serviu como base jurídica para diversas convençóes no âmbito das Cooperaçóes Internacionais, na esfera do Estado também ocorreram vários desdobramentos envolvendo Cooperaçóes Judiciárias, e agora, no Novo Código de Processo Civil, estrutura-se uma normatividade para a Cooperação Jurídica Internacional, estabelecendo, pela primeira vez, um rito, um procedimento de normas-processuais pertinentes a mecanismos de colaboração no plano Internacional entre Estados distintos, que tem como finalidade executar as mais variadas medidas judiciais, como cartas rogatórias, pedidos de transferência de pessoas, homologação de sentenças estrangeiras.

Inclusive já houve grande avanço nesse sentido pela IberRed, denominada Rede Ibero-americana de Cooperação Jurídica, da qual o Brasil faz parte, juntamente com Andorra, Argentina, Bolívia, Chile, Colômbia, Costa Rica, Cuba, Equador, El Salvador, Espanha, Guatemala, Honduras, México, Nicaragua, Panamá, Paraguai, Perú, Portugal, Porto Rico, República Dominicana, Uruguai e Venezuela.

Cabe ainda ressaltar a disposição dos artigos 37 do Novo Código de Processo Civil que define que a "cooperação jurídica internacional oriunda de autoridade brasileira competente será encaminhada à autoridade central para posterior envio ao Estado requerido para dar andamento", bem como o 40, que explana que o pedido de cooperação internacional denominado passivo é aquele que tem por fim a execução a decisão estrangeira.

Vale acrescentar ainda que o artigo 41 do Novo CPC aponta uma limitação com relação à Cooperação Internacional por meio da qual o Brasil poderá se recusar a prosseguir na execução da medida caso isso se ofenda a ordem pública.

Neste sentido, se por um lado, há quem sustente que a análise substancial quanto a possibilidade de avaliação pelo Juízo solicitado da recusa em determinar a busca e apreensão da criança para atender a solicitação do Estado solicitante, sem adentrar, salvo as hipóteses da Convenção, acreditamos que, com a inserção da abertura do sistema para apreciação da "ordem pública” amplie o campo de análise do juízo.

É o que afirma, por exemplo, se deve ou não avaliar a situação da criança e se o seu melhor interesse deve ser guarnecido ao mantê-la junto a um dos pais, no Estado onde ela se encontra em detrimento da sua residência habitual é totalmente inerente à condição para efetivar o artigo 227 e o princípio do melhor interesse da criança; ademais, o próprio artigo 41, do Novo CPC, permite o juiz que se recuse na execução da medida, quando se depara com ofensa a ordem pública.

Ou seja, a "ordem pública” é um elemento de calibração e servirá como uma janela por meio da qual penetra o princípio da Proteção Integral, permitindo ao juízo que ele possa avaliar se a criança realmente deve ou náo retornar para o Estado onde tinha sua residência habitual. 
Finalmente, e ainda no âmbito da efetivação do princípio da Proteção Integral, há uma valiosa contribuição da Convenção da ONU sobre os direitos da Criança, ao dispor no artigo 12 sobre a importância de ouvir a criança em assuntos que envolvam o seu interesse. Neste sentido:

1. Os Estados Partes assegurarão à criança que estiver capacitada a formular seus próprios juízos o direito de expressar suas opinióes livremente sobre todos os assuntos relacionados com a criança, levando-se devidamente em consideração essas opiniôes, em função da idade e maturidade da criança.

2. Com tal propósito, se proporcionará à criança, em particular, a oportunidade de ser ouvida em todo processo judicial ou administrativo que afete a mesma, quer diretamente quer por intermédio de um representante ou órgáo apropriado, em conformidade com as regras processuais da legislação nacional. (CONVENÇÃO, 1990).

Ademais, vale destacar que o artigo 13 da Convenção de Haia já afirmava sobre a importância de se avaliar a manifestação da criança quando ela apresenta discernimento, como fundamento para o juízo recusar-se a cumprir a medida.

Sem prejuízo das disposiçóes contidas no Artigo anterior, a autoridade judicial ou administrativa do Estado requerido não é obrigada a ordenar o retorno da criança se a pessoa, instituição ou organismo que se oponha a seu retorno provar: (...)

A autoridade judicial ou administrativa pode também recusar-se a ordenar o retorno da criança se verificar que esta se opóe a ele e que a criança atingiu já idade e grau de maturidade tais que seja apropriado levar em consideração as suas opiniốes sobre o assunto.

Ao apreciar as circunstâncias referidas neste Artigo, as autoridades judiciais ou administrativas deverão tomar em consideração as informaçóes relativas à situaçáo social da criança fornecida pela Autoridade Central ou por qualquer outra autoridade competente do Estado de residência habitual da criança. (CONVENÇÃO, 1990).

Em matéria de decisóes relacionadas com o sequestro de crianças e seus reflexos no que pertine à guarda e ao Direito Internacional, considerando as transformaçóes decorrentes da superação das fronteiras como obstáculos à mobilidade do homem e da família, levam à necessidade de vários desdobramentos na interpretação do direito pertinente ao princípio da proteção integral e do melhor interesse da criança, considerando o poder familiar, a visitação, a manifestação da criança; o que culmina num estudo transdisciplinar e complexo que não pode se ater aos aspectos meramente formais da Cooperação nem aos estritos termos das normas internas sem adequá-las e contextualizá-las. 


\section{Conclusões}

O mundo mudou, as relações humanas se transformaram, a interpretação jurídica se tornou mais complexa ante a ruptura com a racionalidade e com fixaçáo do fenômeno jurídico restrito à norma.

Novos tempos, novos papéis para o Estado que se afirma Democrático e Social, no qual, a decisão da maioria, para se fixar como Democrático, na verdade é preocupar-se com os valores decorrentes dos Direitos Humanos e dos Direitos Fundamentais.

Nesse sentido, a consagração da dignidade humana como princípio fundamental do ordenamento jurídico brasileiro fortaleceu os Direitos da Criança, reconhecida como titular de prioridade, conforme artigo 227, da Constituição Federal.

Se, sob o prisma global extraíram-se várias Convençóes envolvendo esses sujeitos, no âmbito privado a criança também tratou de ser protegida, por intermédio da uniformização de regras que refletem na atuação dos Estados Contratantes e pertencentes às organismos internacionais. $\mathrm{O}$ mesmo se deu em matéria de convivência familiar.

Neste trabalho procuramos abordar um desses documentos que tem como objeto fulcral a Convençáo sobre os aspectos civis do sequestro internacional de crianças. A despeito dos diversos aspectos tratados, entendemos fundamental partirmos do mandamento nuclear que é o princípio da Proteção Integral e os subprincípios que dele derivam, por exemplo, o Melhor Interesse da criança.

A partir daí, sedimentado o fundamento jurídico, foi possível avaliar sob um prisma transnacional como as cortes e o ordenamento jurídico se preocupam com a tutela da criança quando ela é retirada de seu domicílio por decisão abusiva de um dos seus responsáveis.

Nesse aspecto, consideramos que é imprescindível antes de cooperar com o Estado Contratante, que o Juízo da Vara da Infância e da Juventude avalie a situação da criança, de forma a afastar, sob o nosso prisma, a competência da Justiça Federal, haja vista que aquela é melhor aparelhada e especializada na tutela do infante, mais sensível para considerar a sua manifestaçáo de vontade e melhor preparada para considerar os fatos impeditivos que possam justificar ou não a manutenção da criança no Estado solicitado.

Por fim, tratamos de considerar a preocupação com o Novo Código de Processo Civil quanto a fixaçáo de um rito procedimental no que pertine a execuçáo de medidas para atos de Cooperação Internacional, tendo inclusive a ordem pública como elemento normativo de calibração para o Juízo aferir se as solicitaçóes feitas pelo Estado Contratante devem ou náo prosperar para serem cumpridas e executadas no Brasil, obviamente, no que pertine a Convenção em questão neste trabalho. 


\section{Referências}

BARATTA, Alessandro. La situación de la protección del niño en America Latina: líneas de una investigación-acción sobre los derechos de los niños. Capitulo Criminológico, Maracaibo, v. 18-19, p. 159-175, 1990-1991.

. Elementos de un nuevo derecho para la infancia y la adolescência: a proposito del Estatuto del niño y del adolescente de Brasil. Capitulo Criminológico, Maracaibo, v. 23, n. 1, p. 1-18, jan./jun. 1995.

. Os direitos da criança e o futuro da democracia. In: et al. Perspectivas do Direito no início do século XXI. Coimbra: Coimbra Editora, 1999, p. 61-91.

BRASIL. Código de Processo Civil. Disponível em: < http://www.planalto.gov.br/ccivil_03/_Ato2015-2018/2015/Lei/L13105.htm>. Acesso em: 15 mai. 2015.

BUSTOS RAMÍREZ, Juan. Perspectivas de un Derecho Penal del Niño. Nueva Doctrina Penal, Buenos Aires, v. A, p. 63-71, 1997.

CAMARGO SOBRINHO, Mário. Algumas consideraçóes sobre o adolescente infrator face à legislação nacional e alienígena. Revista Jurídica da Universidade de Franca, Franca, v. 3, n. 4, p. 99-116, mai. 2000.

CONVENÇÃO Americana de Direitos Humanos = PACTO de San José da Costa Rica. 22 nov. 1969. Disponível em: <http://pge.sp.gov.br/centrodeestudos/bibliotecavirtual/instrumentos/sanjose.htm.>. Acesso em: 5 abr. 2015.

CONVENÇÃO de Haia. 25 outubro 1980. Disponível em: <http://www.stf.jus.br/arquivo/cms/convencaoHaiaConteudoTextual/anexo/textoConvencao.pdf $>>$. Acesso em: 8 mai. 2015 .

CONVENÇÃO sobre os Direitos da Criança. 14 setembro 1990. Disponível em: <http://www.planalto.gov.br/ccivil_03/decreto/1990-1994/D99710.htm>. Acesso em: 10 abr. 2015.

COSTA, Ana Paula Motta. As garantias processuais e o Direito Penal Juvenil como limite na aplicação da medida socioeducativa de internação. Porto Alegre: Livraria do Advogado, 2005.

DECLARAÇÃO Universal dos Direitos Humanos = Universal Declaration of Human Rights. 10 dezembro 1948. Disponível em: <http://www.humanrights.com/pt/what-are-human-rights/universal-declaration-of-human-rights/articles-21-30.html> Acesso em: 13 abr. 2015.

DOLINGER, Jacob. Direito internacional privado: a criança no direito internacional. Rio de Janeiro: Renovar, 2003. 
GARCÍA MÉNDEZ, Emilio. La Convención Internacional de los Derechos de la Infancia: del menor como objeto de la compasión-represión a la infancia-adolescencia como sujeto de derechos. Capitulo Criminológico, Maracaíbo, n. 18/19, p. 177-193, 1990.

. Política de la infancia/adolescencia en América Latina. Estado, movimiento social y modelo jurídico-institucional: tendencias y perspectivas. Doctrina Penal: Teoría y práctica en las Ciencias Penales, Buenos Aires, a. 14, n. 55/56, p. 479-489, jul./dez. 1991.

. Infancia, ley y democracia: uma cuestión de justicia. Ciencias Penales: Revista de la Asociación de Ciencias Penales de Costa Rica, Costa Rica, a.10, n. 15, p. 58-71, dez. 1998.

GASPAR, Renata Alvares; AMARAL, Guilherme. Sequestro internacional de menores: os tribunais brasileiros têm oferecido proteção suficiente ao interesse superior do menor? Meritum, Belo Horizonte, v. 8, n.1 p. 351-387, jan./jun. 2013.

JAYME, Erik. Direito internacional privado e cultura pós-moderna. Revista Caderno de Pós Graduação em Direito do Programa de Pós-Graduação em Direito da UFRGS, Porto Alegre, n. 1, v. 1, p. 105-114, 2003.

KONZEN, Afonso Armando. Reflexôes sobre a medida e sua execução (ou sobre o nascimento de um modelo de convivência do jurídico e do pedagógico na socioeducação). In: ILANUD et al. (Org.). Justiça, adolescente e ato infracional: socioeducação e responsabilização. São Paulo: ILANUD, 2006. p. 343-365.

LUCCHINI, Riccardo. Le débat brésilien sur la Justice des Mineurs. Déviance et Societé, Liège, v. 15, n. 2, p. 175-186, 1991.

MACHADO, Martha de Toledo. Sistema especial de proteção da liberdade do adolescente na Constituição brasileira de 1988 e no estado da criança e do adolescente. In: ILANUD et al. (Org.). Justiça, adolescente e ato infracional: socioeducação e responsabilização. São Paulo: ILANUD, 2006. p. 87-121.

MARINONI, Luiz Guilherme. Curso de processo civil: teoria geral do proceso. 3. ed. São Paulo: Revista dos Tribunais, 2008. v.1.

MONACO, Gustavo Ferraz de Campos. A Declaração Universal dos Direitos da Criança e seus sucedâneos internacionais: tentativa de sistematização. Coimbra: Coimbra, 2004.

PASSETT, Edson. Violentados: crianças, adolescentes e justiça. São Paulo: Imaginário. 1995.

PIMENTEL, José Menéres. Perspectiva do direito no início do século XXI. Coimbra: Coimbra Editora, 1999. p. 41-59. 
RODAS, João Grandino; MÔNACO, Gustavo Ferraz de Campos. A Conferência da Haia de direito internacional privado: a participação do Brasil. Brasília: Fundação Alexandre de Gusmão, 2007.

SAENZ, Fabiana Eduardo. Política Criminal e limite etário de responsabilização penal. 2008. 218f. Dissertação (Mestrado em Criminologia) - Faculdade de Direito, Universidade de São Paulo, [2008].

SARAIVA, João Batista Costa. Compêndio de Direito Penal Juvenil: adolescente e ato infracional. 3. ed. Porto Alegre: Livraria do advogado, 2006.

SIFUENTES, Mônica. Sequestro Interparental: a experiência brasileira na aplicação da Convenção de Haia de 1980. Julgar, Lisboa, n. 8, p. 225-233, 2009.

SHECAIRA, Sérgio Salomão. Sistema de Garantias e o Direito Penal Juvenil. São Paulo: Revista dos Tribunais, 2008.

SIFUENTES, Mônica. Sequestro interparental: a experiência brasileira na aplicação da Convenção de Haia de 1980. Revista SJRJ, Rio de Janeiro, n. 25, p. 135-144, 2009.

SOTOMAYOR, Carlos Tiffer. De un Derecho Tutelar a un Derecho Penal MínimoIGarantista: nueva Ley de Justicia Penal Juvenil. Ciencias Penales .Revista de la Asociación de Ciencias Penales de Costa Rica, San José , n. 13, p. 98-109, ago. 1997.

SPOSATO, Karyna Batista. O Direito Penal Juvenil. São Paulo: Revista dos Tribunais, 2006.

TEIXEIRA, Carla Moura. Direito internacional para o século XXI. São Paulo: Saraiva, 2013.

VINCENTIN, Maria Cristina. A questão da responsabilidade penal juvenil: notas para uma perspectiva ético-política. In: ILANUD et al. (Org.). Justiça, adolescente e ato infracional: socioeducação e responsabilização. São Paulo: ILANUD, 2006. p. 151173.

ZAFFARONI, Eugenio Raúl. Minorias desplazadas, delincuencia y poder punitivo. Eguzkilore. Cuaderno del Instituto Vasco de Criminología, San Sebastián, n. 7 (ext.), p. 83-92, dez. 1994. 